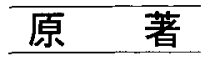

持続型方向交代性下向性頭位眼振の検討

一條 宏明

\title{
Persistent Type of Geotropic Direction-changing Positional Nystagmus
}

Hiroaki Ichijo

Ichijo Ear, Nose and Throat Clinic

Geotropic direction-changing positional nystagmus is considered to be caused by canalolithiasis of the horizontal semicircular canal. However, horizontal nystagmus, which persists without decreasing over time, can not be explained by canalolithiasis. The pathophysiology of the persistent type of geotropic direction-changing positional nystagmus is considered to be a result of light debris cupulolithiasis of the horizontal semicircular canal. In the supine position, permanent horizontal nystagmus toward the intact side is observed. In neutral position 1, with the head turned about 30 degrees to the affected side, the nystagmus decreases and eventually stops. With greater headturn, nystagmus toward the earth lasts for more than one minute. These phenomena are considered to indicate that the cupula is deflected by the buoyancy of attached light debris which is hypodense compared with the endolymph. In the nose-down position, persistent horizontal nystagmus to the affected side is detected. In neutral position 2, with the head turned about 30 degrees to the affected side, the nystagmus stops. To evaluate Ewald's first law, we quantitatively compared horizontal nystagmus in the supine position and that in the nose-down position with the use of video-oculography. The patients were fifteen women and four men with persistent horizontal positional nystagmus toward the ground, ranging in age from 23 to 83 years (average, 59.2 years). They had no evidence of neurologic disease. In fifteen patients (78.9\%), the maximum slow phase velocity in the nose-down position was greater than that in the supine position. Therefore, an ampullopetal deviation of the horizontal semicircular canal cupula was considered to bring about stronger nystagmus than an ampullofugal displacement of the cupula.

Key words: Ewald's first law, direction-changing positional nystagmus, cupulolithiasis, light debris, horizontal semicircular canal

はじめに

末梢性頭位性めまい症は扮扮む视後半規管型と 外側半規管型に分類でき，その病態はかなりの部

一條耳鼻咽喉科クリニック
分まで明らかになってきたり〜4)。後半規管型は懸 垂頭位で回旋成分の強い眼振を呈し，治療法であ る浮遊耳石置換法に関しても多くの施設でその有 効性が確かめられている5) -7)。

他方，外側半規管型は側臥位で水平性眼振を呈 


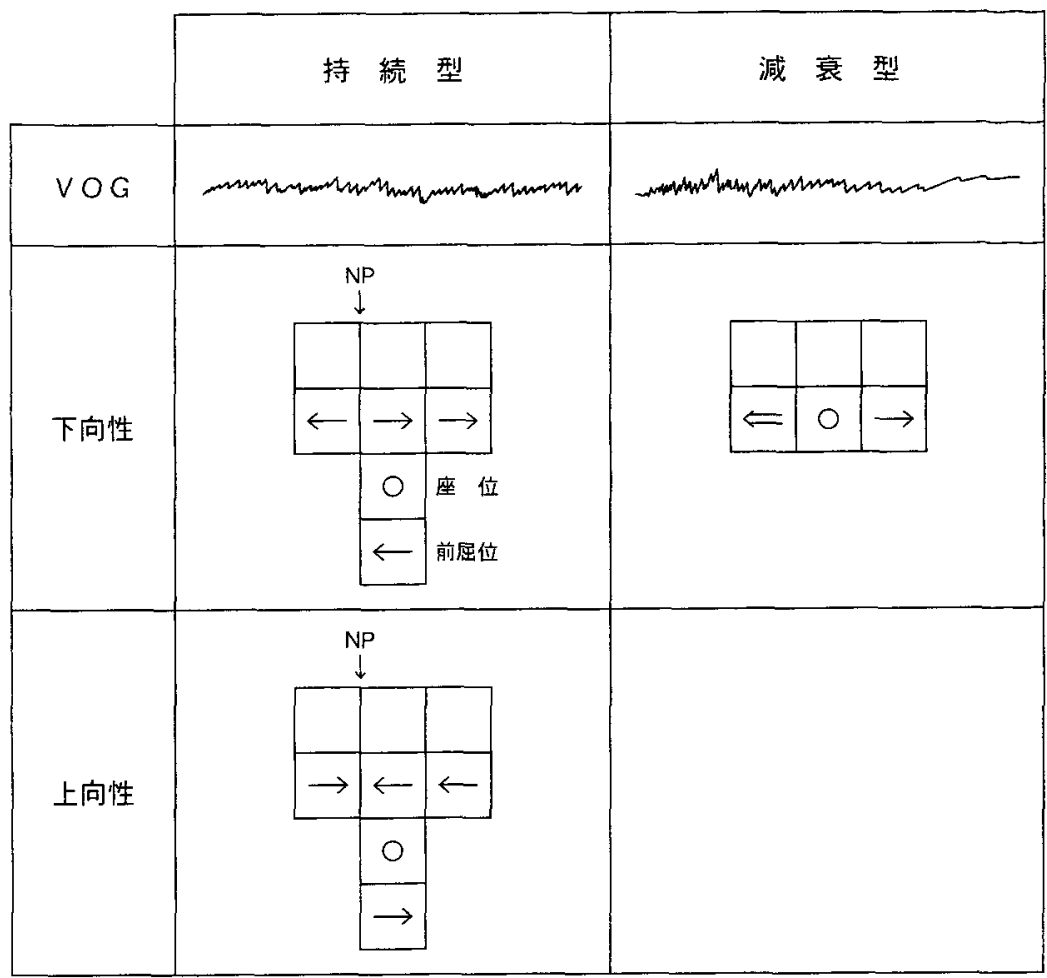

図 1 外側半規管型頭位性めまい症の分類（患側：右）

方向交代性下向性頭位眼振は持続型之減衰型の 2 つに分類でき，方向交代性上向性頭位眼振は例外なく持 続型である。

VOG: video-oculography, NP: neutral position（眼振停止点）。

し，その頭位眼振の方向と性状から 3 つ分類で きる（図 1)。外側半規管クプラに重い固体成分 が付着した場合は，側臥位でクプラが重力方向へ 持続的に屈曲するため結果的に反重力方向へ水平 性眼振が出現すると考光られる899)。したがって 万向交代性上向性頭位眼振は例外なく 1 分以上持 続し，また外側半規管クプラが矢状面に平行に位 置していないという解剖学的事象から，仰卧位で もクプラは屈曲し持続型の患側向き水平性眼振を 呈する。

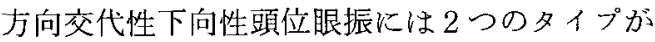
存在する。側臥位での眼振が $20 \sim 30$ 秒で減衰し停 止する減衰型と，1分以上持続し減衰傾向に之し い持続型である。前者は浮遊耳石理論によって説 明可能であり, 後者はクプラ結石の場合とは逆に, 内リンパ液よりも比重の小さな浮遊物が一側の外 側半規管クプラに付着した病態を想定すると，頭 位眼振の特徵が矛盾なく説明できる10111。
この軽いクプラ理論が正しく，仰臥位と前屈位 でのクプラの变位角度が同じだと仮定すると，仰 卧位に和ける眼振と前屈位に打汀る眼振の美異を 比較することで Ewald の第一法則の妥当性が検 討できる。以上の研究目的で，持続型方向交代性 下向性頭位眼振 VOG（video-oculography）に より定量的炕解析したので報告する。

\section{対 象}

対象症例は平成15年 8 月から平成17年12月まで に頭位变換時のめまいを主訴として当院を受診 し，以下の条件を満たした外側半規管型頭位性め まい症19例である。

1）側臥位において重力方向に向から水平性眼 振を認めるが，短時間には減衰せず１分以上持続 する。

2）仰臥位に执いても持続型の水平性眼振を認 める。

3）仰臥位からいずれかの方向へ30度程度（こ 
の角度は個人差が大きい）捻転すると眼振が停止 する neutral position 1 望める。

4) 座位を保つと眼振は停止し，そこからさら に90度前屈させると仰臥位の場合とは反対方向一 の持続型眼振を認め，いずれかの方向へ 30 度程度 （この角度は個人差が大きい）捻転すると眼振が 停止する neutral position 2 を認める。

5）予後は良好で早ければ数日以内, 逢くとも 2 力月以内にはめまいと眼振は消失する。

6）め要いと関連した蝸牛症状はなく，中枢神 経障害なし（神経症状はなく，MRIやCTにて 甩頭蓋内病変を認めない)。

\section{方法}

頭位眼振検査は通常の頭位に加克, 座位と前屈 位（座位で90度頭部前屈させる頭位）において 行った。ひとつの頭位を 1 分以上維持し減衰傾问 のないことを確認した。

初診時に括ける眼振を赤外線 CCD カメラを用 いてビデオ録画した後，山口大方式による眼振解 析法 ${ }^{12)}$ により VOG (video-oculography) として
グラフ化し，仰臥位における眼振の水平成分の緩 徐相速度之, 前屈位に和ける眼振の水平成分の緩 徐相速度を用手的に計測した。な抏，仰卧位，前 屈位ともに眼振が安定した部分を数为所計測し平 均值を求めた。

また，VOGをもとに眼振の垂直成分と回旋成 分の有無を検討した。

\section{結 果}

\section{1。性別と年齢}

女性15例, 男性 4 例, 平均年齢は59.2歳であ。 た。

\section{2. 眼振の水平成分の緩徐相速度}

19例中15例（78.9\%）で前屈位の緩徐相速度の 万が仰臥位の緩徐相速度よりも大きかった。3例 では差がなく，1例では逆に仰卧位の方が前屈位 よりも緩徐相速度が大きかった（表 1，図 2)。

3 . 眼振の垂直成分

仰臥位では 4 例 (21.1\%) 飞垂直成分が認めら れ，らち 3 例では上眼瞼向き，1例では下眼瞼向 きであった。前屈位では14例 (73.7\%) 亿垂直成

表 1 刘象症例抏よび計測結果 空欄住不明

\begin{tabular}{|c|c|c|c|c|c|c|c|c|c|c|}
\hline \multirow{2}{*}{ 症例 } & \multirow{2}{*}{ 年齢 } & \multirow{2}{*}{ 性別 } & \multirow{2}{*}{ 発症時刻 } & \multirow{2}{*}{ 病日 } & \multicolumn{2}{|c|}{ 仰臥位における眼振 } & \multicolumn{2}{|c|}{ 前屈位に蛙ける眼振 } & \multicolumn{2}{|c|}{ 眼振緩徐相速度 $\left({ }^{\circ} /\right.$ 秒 $)$} \\
\hline & & & & & 回旋成分 & 垂直成分 & 回旋成分 & 垂直成分 & 仰臥位 & 前屈位 \\
\hline 1 & 23 & 女 & 起床時 & 3 & + & + & + & + & 2.1 & 4.3 \\
\hline 2 & 34 & 女 & 起床時 & 1 & + & + & + & + & 5.7 & 11.4 \\
\hline 3 & 43 & 女 & 就垵時 & 4 & - & - & - & - & 2.1 & 2.9 \\
\hline 4 & 44 & 女 & & & - & - & + & + & 2.9 & 2.9 \\
\hline 5 & 47 & 女 & 起休時 & 4 & - & - & - & + & 5.7 & 6.4 \\
\hline 6 & 50 & 男 & 起休時 & 2 & - & - & - & - & 3.6 & 7.9 \\
\hline 7 & 54 & 女 & 睡眠中 & 30 & - & - & - & - & 7.1 & 10 \\
\hline 8 & 55 & 男 & 夕方 & 2 & - & + & - & + & 9 & 13. 6 \\
\hline 9 & 57 & 女 & & 3 & - & + & - & + & 5 & 7.9 \\
\hline 10 & 58 & 女 & 起床時 & 4 & - & - & + & + & 7. 1 & 14.3 \\
\hline 11 & 62 & 女 & 起床時 & & - & - & - & - & 4. 3 & 6.4 \\
\hline 12 & 70 & 女 & 夕方 & 2 & - & - & - & + & 12.9 & 8.6 \\
\hline 13 & 71 & 女 & 起床時 & 6 & - & - & - & + & 5 & 6.4 \\
\hline 14 & 74 & 女 & 午後 9 時 & 7 & - & - & - & + & 2.9 & 4.3 \\
\hline 15 & 74 & 女 & 就寝時 & 2 & - & - & - & - & 2.9 & 2.9 \\
\hline 16 & 74 & 女 & & 3 & - & - & - & + & 5.7 & 11.4 \\
\hline 17 & 75 & 女 & 夕方 & 2 & + & - & - & + & 7.9 & 25.7 \\
\hline 18 & 76 & 男 & 起床時 & 4 & + & - & + & + & 4.3 & 7.9 \\
\hline 19 & 83 & 男 & 夕方 & 3 & - & - & + & + & 4.3 & 4.3 \\
\hline
\end{tabular}




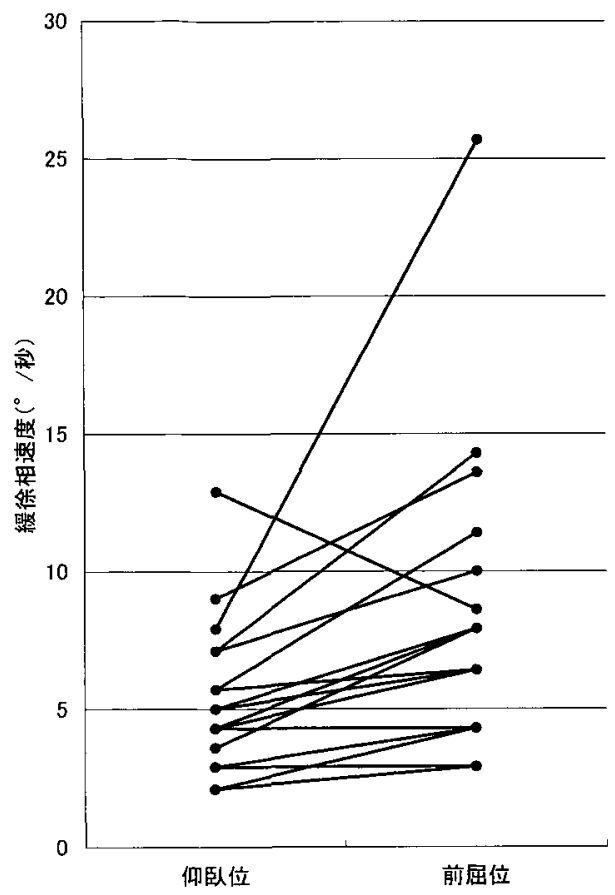

図 2 仰卧位における眼振と前屈位における眼振 差

前屈位の力が眼振緩徐相速度が大きい傾向 にあった。

分が認められ全例下眼瞼向さであった。

4. 眼振の回旋成分

仰臥位で 4 例 (21.1\%) に回旋成分を認め，前 屈位では6 例 $(31.6 \%)$ に認められた。図3に央 祭の VOGを示した。

\section{考察}

老人性難聴を除くと，頭位性めまい症は最名頻 度の高い内耳疾患である。懸垂頭位で回旋成分の 強い眼振を呈する場合は，良性発作性頭位めむい 症と称され50年以上も前から認知されているが， 側卧位で水平成分の強い眼振を呈する症例も少な からず存在し13)，それらはその頭位眼振の性状か ら考奌外側半規管が責任病巣と考兄られる。

外側半規管型頭位性めまい症は方向交代性上向 性頭位眼振と方向交代性下向性頭位眼振の2 つに 大別できる。方向交代性下向性頭位眼振にはさら に2つのタィプが存在する。20～30秒で減衰し停 上与る減衰型と，1分以上持続し減衰傾向に之し い持続型である（図 1)。前者は浮遊耳石理論に よって説明可能であり，後者は軽い浮遊物が一側

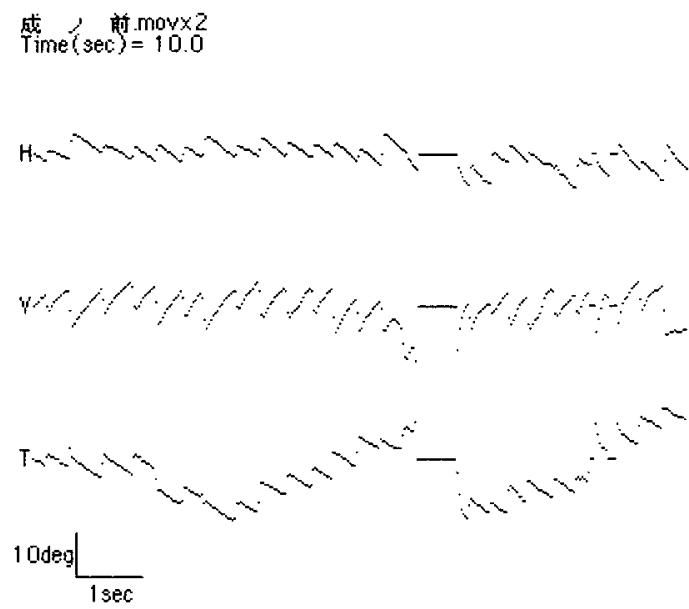

図 3 症例100前屈位に括けるVOG 水平成分 $(\mathrm{H})$ は右向き，垂直成分 (V) は下眼臉向き，回旋成分（T) 怡右向きで 西り，減衰傾向に乏しい。平坦な部分は閉 眼である。

の外側半規管クプラに付着した病態を想定する と，頭位眼振の特徽が矛盾なく説明でさる（図 4)。すなわち，仰臥位ではクプラが浮力によっ て反重力方向（反膨大部方向）に変位して健側向 き持続型眼振が生じるが，患側下の側卧位では健 側方向に持続的に屈曲するため結果的に眼振は患 側方向（重力方向）に出現する。反対に健側下頭 位では患側のクプラは患側方向に屈曲するため, 眼振は健側方向（重力方向）に生しる。前屈位で は仰臥位の場合とは反対に，持続的に健側方向 （向膨大部方向）に変位するため，患側向き眼振 が出現する。

ただし，以上の理論は外側半規管のクプラの先 端が外側を向いているといら解剖学的事象を前提 としている。一般に頭蓋骨の大きさや形状は個人 差があり，左右の垂直半規管のなす角度乎個人差 が大き(14)15)。多くの場合は外側半規管のクプラ の先端が外側を向いていると考光られるが4)，可 ベての症例に当てはまるとは断言できない。この 点は今後の解剖学的検証が待たれるところであ る。

軽いクプラ理論によって方向交代性下向性頭 位眼振を説明した報告は過去にいくつかある が4)10111，この理論に和ける最大の問題点は，内 リンパ液よりも比重の小さな浮遊物が存在するか 


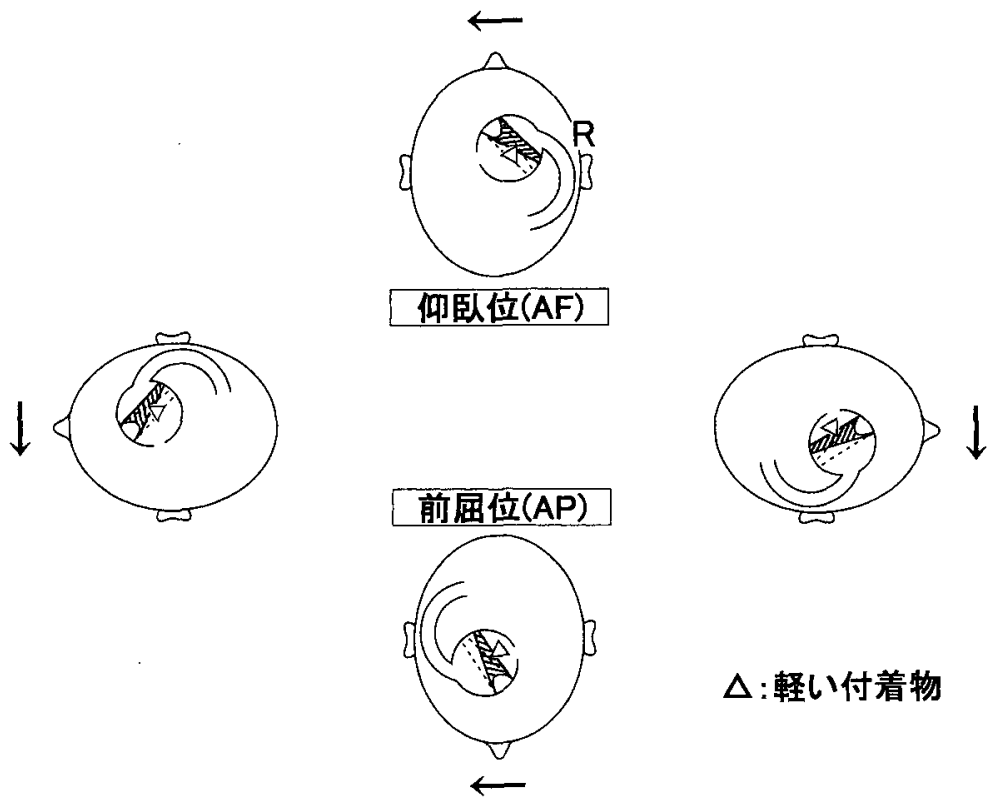

図 4 持続型方向交代性下向性頭位眼振の病態（患側 : 右）

仰臥位でも軽い付着物によって外側半規管クプラが反重力方向に变位し，健側向き眼振を呈する。前屈位 では反対に患側向き眼振を是する。矢印は眼振方向。

AF: ampullofugal（反膨大部方向），AP: ampullopetal（向膨大部方向）。

どらかといら点である。軽い浮遊物の可能性とし て, 遊離した細胞が時間経過とともに変性して体 積が増光結果的に比重が小さくなった場合が考兄 られる。リスザルでの組織学的検討では, 内リン パ霅や後半規管膨大部に単球やリンパ球などの細 胞のかたまりが浮遊していることが確認されてい る16)。また, 脱落した耳石が化学変化を起こした ため二酸化炭素などの気体成分を生産した可能性 もある。耳石の主成分は炭酸カルシウム $\left(\mathrm{CaCO}_{3}\right)$ であり，式量は $100.09 て ゙$ 密度は $2.711 \mathrm{~g} / \mathrm{cm}^{3}$ であ るから，耳石に不純物がなければ比重は2.711と 内リンパ液の比重1.008よりもかなり大きい。し たがって耳石自体が変化して軽くなるとは考党に くいが，以下のいずれかの化学反応が起きれば二 酸化炭素 $\left(\mathrm{CO}_{2}\right)$ が生成され，気泡が発生する。

$$
\begin{aligned}
& \mathrm{CaCO}_{3} \rightarrow \mathrm{CaO}+\mathrm{CO}_{2} \uparrow \\
& \mathrm{CaCO}_{3}+\mathrm{H}_{2} \mathrm{O} \rightarrow \mathrm{Ca}(\mathrm{OH})_{2}+\mathrm{CO}_{2} \uparrow \\
& \mathrm{CaCO}_{3}+2 \mathrm{HCl} \rightarrow \mathrm{CaCl}_{2}+\mathrm{H}_{2} \mathrm{O}+\mathrm{CO}_{2} \uparrow
\end{aligned}
$$

（a）は熱分解反応なので $36^{\circ} \mathrm{C}$ では起こりにく いが, 内リンパ夜には $\mathrm{H}_{2} \mathrm{O}$ \& $\mathrm{H}^{+}, \mathrm{Cl}^{-}$も微量で はあるが存在するので（b），(c）の反応は起こり 得る。発生した気泡が微量であっても, クプラの 先端部分に付着すると，てこの原理によってクプ ラを屈曲し得ると考克ら机る。

軽いクプラ理論を説明するらえで, Money ら ${ }^{17)}$ が提唱したアルコール性頭位眼振が参考になる が、この浮力説では現象を十分には説明できない。 血中のアルコールがクプラに移行し相対的に軽く なったとするならば，6つの半規管のクプラがす べてが軽くなるはずである。すると側臥位では後 半規管や前半規管も同時に刺激され, 出現寸る眼 振は垂直成分や回旋成分を伴った複雑な眼振にな るはずであり，また座位でも両側の前半規管が刺 激され垂直性眼振が出現するはずである。ところ が実際のアルコール性頭位眼振は側卧位でのみ出 現する水平性の方向交代性下向性頭位眼振であ る。血行動態から考えて, 外側半規管のクプラの みに選択的にアルコールが移行するとは考兄にく く,アルコール性頭位眼振の解釈には疑問が残る。 さしろアルコールにより小脳の抑制が低下したた めに出現した中枢性眼振の可能性がある。

Ewald の第一法則とは，半規管に生じる内リン 
パ流動に関する法則で，外側半規管の向膨大部流 は刺激として作用し，反膨大部流は抑制として働 くとするものである。有毛細胞の配列の形態学的 特徵から考光ればこの法則は妥当と考兄られる が，向膨大部流の方が反膨大部流よりも強い眼振 を生じさせるかどらかについては定の結論が得 られていない。しかしながら，ここでは便宜上 Ewald の第一法則を「向膨大部流の方が反膨大部 流よりも強い眼振をもたらす」と拡大解积するこ ととする。

持続型方向交代性下向性頭位眼振に打ける軽い クプラ理論が正しく, 仰臥位と前屈位でのクプラ の变位角度が同じたと仮定すると，多くの症例 (78.9\%) 飞おいて前屈位の眼振の緩徐相速度が 仰臥位の眼振のそれよりも大きかったといら今回 の結果は Ewald の第一法則に基づいて説明可能 である。

また，減害型の方向交代性下向性頭位眼振の病 態は外側半規管内の浮遊耳石と考兄られ，仰卧位 から患側方向へ頭部捻転した時の方が健側方向へ 捻転した時よりも強い眼振が出現する。このこと も Ewald の第一法則に基づいて説明可能である。

外側半規管型頭位性めまい症の頭位眼振におい て，回旋成分や垂直成分が混じることがある。こ れらが後半規管や前半規管に由来する可能性もあ るが，軽い浮遊物が外側半規管クプラと垂直半規 管クプラに同時に付着するという確率は極めて低 く，生た後半規管は解剖学的に最も後方で下方に 位置しているので，軽い浮遊物は付着しにくいと 考えられる。興味深い点は, 前屈位で高頻度に垂

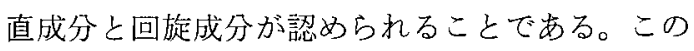
現象は視運動性後眼振に打ける三次元特性 (cross-coupling) 想起させる。すなわち，座位 における通常の視運動性後眼振は水平成分のみで 垂直成分は認められないが，側卧位では垂直成分 が，仰臥位や腹臥位では回旋成分が混じるといら 現象である18)。これは頭部に作用する重力の方向 の変化が速度蓄積機構に影響を与学をといら証拠 であり，外側半規管動眼反射に対しても速度蓄積 機構を介して同様の機序が動き垂直成分と回旋成 分が出現した可能性がある。しかしなぜ前屈位の 方が仰卧位よりも垂直成分, 回旋成分ともに出現 頻度が高いのかについては不明である。

\section{まとめ}

末梢性の持続型方向交代性下向性頭位眼振症例 において,

1）前屈位での眼振の水平成分の緩徐相速度は仰 卧位におけるそれよりも大きい例が多かった。

2) 病態を一側の外側半規管の軽いクプラと仮定 すると，向膨大部方向のクプラの变位の方が反膨 大部方向のそれょりも強い眼振をもたらすのでは ないかと考㝋られた。

3）眼振の回旋成分と垂直成分に関しては，いず れ女前屈位に扎いて高頻度に認められた。

\section{文献}

1）重野浩一郎：頭位眼振の分類とその意義. Equilibrium Res 59: 254-265, 2000

2 ) 鈴木 衞: 方向交代性頭位眼振の臨床. 耳鼻 臨床 93: 177-183, 2000

3）武田憲昭：良性発作性頭位女末い症一臨床疫 学々病態生理一。耳鼻臨床 94: 763-776, 2001

4) 高石 司: 外側半規管型良性発作性頭位內ま い症の臨床. Equilibrium Res 61: 412-419, 2002

5 ) Epley JM: The canalith repositioning procedure; for treatment of benign paroxysmal positional vertigo. Otolaryngol Head Neck Surg 107: 399-404, 1992

6 ）一條宏明, 阿部聡子, 石井賢治, 他：頭位脑 量症に刘する浮遊耳石置換法の効果. 耳鼻臨 床 89: 299-304, 1996

7 ) Prokopakis EP, Chimona T, Tsagournisakis M, et al: Benign paroxysmal positional vertigo: 10-year experience in treating 592 patients with canalith repositioning procedure. Laryngoscope 115: 1667-1671, 2005

8) Bisdorff AR, Debatisse D: Localizing sings in positional vertigo due to lateral canal cupulolithiasis. Neurology 57: 1085-1088, 2001

9) 重野浩一郎：外側半規管のクプラ結石症とク プラの位置. Equilibrium Res 61: 97-98, 2002

10) Hiruma $K$, Numata $T$ : Positional nystagmus showing neutral points. ORL J Otorhinolaryngol Relat Spec 66: 46-50, 2004

11）一條宏明：持続型方向交代性下向性頭位眼振 の病態.耳鼻臨床 97: 781-787, 2004

12）池田卓生, 橋本 誠, 堀池 修, 他: NIH 
Image を用いた簡易眼球運動画像解析法一三 次元解析と回転軸解析について一. Equilibrium Res 61: 90-96, 2002

13）林裕次郎，國弘幸伸，東野一隆，他：方向交 代性頭位眼振の臨床的検討. Equilibrium Res 59: 198-205, 2000

14) Blanks RHI, Curthoys IS, Markham CH: Planar relationships of the semicircular canals in man. Acta Otolaryngol 80: 185-196, 1975

15）一條宏明：左右の後半規管拈上び前半規管の なす角度に関する研究，日耳鼻会報 105: 1138-1142, 2002

16) Yamane H, Igarashi M: Free-floating cells in the endolymphatic sac after surgical utricular nerve section. ORL J Otorhinolaryngol Relat
Spec 46: 289-293, 1984

17) Money KE, Johnson WH, Corlett BMA: Role of semicircular canals in positional alcohol nystagmus. Am J Physiol 208: 1065-1070, 1965

18) Raphan T, Cohen B: Organizational principles of velocity storage in three dimensions. The effect of gravity on cross-coupling of optokinetic after-nystagmus. Ann N Y Acad Sci 545: 74-92, 1988

原稿到着：平成18年3月17日

別刷請求先：一條宏明

干036-8002 青森県弘前市駅前3-2-1

イトーヨーカドー $6 \mathrm{~F}$

一條耳鼻咽喉科》リニック 